\title{
Present status of rearing backyard poultry in selected areas of Mymensingh district
}

\author{
MA Alam*1, MS Ali ${ }^{2}$, NG Das ${ }^{1}$, MM Rahman ${ }^{1}$ \\ ${ }^{1}$ System Research Division, Bangladesh Livestock Research Institute, Savar, Dhaka 1341; ${ }^{2}$ Department of \\ Poultry Science, Bangladesh Agricultural University, Mymensingh 2202, Bangladesh
}

\begin{abstract}
This study was conducted in Boyra and Sutiakhali villages under Sadar upazila of Mymensingh district to know the present status of backyard poultry production system. The survey data were collected from 40 randomly selected farmers having 20 from each village by interviewing them. The data were then analyzed statistically. All the selected farmers reared deshi chicken and about $54 \%$ of them reared deshi duck only. It was also found that highest proportion (75\%) of farmers reared both chicken and duck together, followed by $17.5 \%$ reared only chicken and $7.5 \%$ reared chicken, duck and pigeon at a time. The average population per household of chicken, duck and pigeon were 10.4, 9.95 and 4.0, respectively, in both villages. All farmers reared poultry in semi-scavenging system. About $55 \%$ farmers kept poultry in their dwelling house. Farmers were used boiled rice, rice polish, paddy and broken rice to fed the birds. About $62 \%$ farmers were used rice and rice polish to make diet for chicken and ducks. Farmers provided around $49 \mathrm{~g}$ and $108 \mathrm{~g}$ supplemental diet to each chicken and duck per day, respectively and about $65 \%$ farmers provided this diet twice a day. Majority of farmers did not use feeder and waterer (about $75 \%$ and $87.5 \%$ respectively). Age at sexual maturity of Chicken and duck were around 189 days and 195 days, respectively. Adult weight of chicken and duck were $1192.5 \mathrm{~g}$ and $1690 \mathrm{~g}$, respectively. The weights of chicken and duck eggs were 39.02 and $62.5 \mathrm{~g}$, respectively. The hatchability of chicken and duck eggs ranged between $69-80 \%$ and $76-90 \%$ with an average of 75.97 and $83 \%$, respectively. Majority of the farmers mentioned that the most prevalent diseases of chicken and duck were New castle and cholera (about $51 \%$ and $49 \%$, respectively). A large number of farmers $(86 \%)$ did not vaccinate their poultry. Mortality of chicken and duck were calculated about $28 \%$ and $20 \%$, respectively. Farmers collected chicks and ducklings from market and neighbor but most of the farmers ( $50 \%$ for chicks and $43 \%$ for ducks) incubate eggs under the broody hen. It was concluded that backyard poultry farmers are low producers and chicken and duck were found to be the most common poultry species reared by the farmers.
\end{abstract}

Key words: Backyard poultry, present status, producers, semi-scavenging system

Bangladesh Animal Husbandry Association. All rights reserved. Bang. J. Anim. Sci. 2014.43 (1): 30-37

\section{I ntroduction}

Bangladesh has a long historical record of raising poultry under backyard system. Poultry plays a vital role in the subsistence economy and contribute $1.6 \%$ in GDP (SAEDF 2008) in Bangladesh. Village poultry are usually regarded as a "Walking Bank" or "Bank Coin" for the poor families. The per capita meat and egg consumption in Bangladesh is one of the lowest in the world. The average per capita meat and egg requirement is $43.25 \mathrm{~kg}$ and 104 numbers, respectively and the available values are only $9.12 \mathrm{~kg}$ and 36 numbers per year (FAO/APHCA
2008). To reduce the gap between demand and supply of animal protein, poultry can play an important role. Moreover, poultry meat has a great demand as compared to other varieties of meat simply because of the socio-economic limitations and religious taboos on pork and beef (Jabbar et al. 1983). In Bangladesh, the meat and eggs of deshi chicken are more attractive to the consumer in both urban and rural areas (Das 1995). Bangladesh and many other developing countries, the meat and eggs of indigenous chicken are highly preferred for their taste and suitability for special dishes resulting in even higher market prices for these chickens than their

\section{${ }^{*}$ Corresponding Author: apple_bau118@yahoo.com}


exotic counterpart (Islam and Nishibori 2009). Scavenging system of poultry rearing is a century old traditional production system of the country. Indigenous chicken serve as an investment and source of security for households in addition to their use as sources of meat and eggs for consumption and of income (Muchadeyi et al. 2007). Villagers who cannot afford to maintain the stock of cattle or goat can presumably maintain a few stocks of chicken, duck and/or pigeon. However, the rural farmers do not have much knowledge on different aspects of poultry management. Despite their importance indigenous breeds are under threat due to various factors such as changing production systems and indiscriminate crossbreeding (Besbes 2009). However, sufficient knowledge on backyard poultry rearing in this respect is required. There is a paucity of systematic data on rural poultry production. Therefore the study was undertaken to know the present status of rearing backyard poultry and assessing the extent knowledge of the farmers in respect of breeding, feeding, housing, prevention and control of diseases on poultry.

\section{Materials and Methods}

Two villages under Sadar upazila of Mymensingh district and forty farmers having 20 from each village were selected purposefully and randomly. The selected areas (Boyra and Sutiakhali) and farmers were considered on the basis of their traditional crop production combined with livestock and small-scale poultry production system. The data were collected by interviewing with a fill up questionnaires on farmers knowledge regarding of backyard poultry rearing. Some parameters like feed weight, egg weight and body weight were recorded directly by the researchers. Collected data were analyzed in accordance with the objectives of the study. Mean, standard deviation and percentage were used mainly to illustrate the results.

\section{Results and Discussion}

\section{Rearing of backyard poultry}

Farmers seldom rear all the three types of poultry birds; chicken, duck and pigeon at the same time. Some rear chicken only, some chicken with duck and some all the three types of birds. It was found that highest proportion (75\%) of farmers reared both chicken and duck together rather than rearing other species at a time (Figure 1 ). Thus, chicken and duck were found to be the most common poultry species reared by the farmers in both villages.

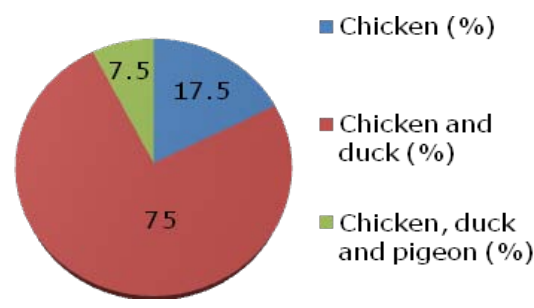

Figure 1. Rearing pattern of backyard poultry

In case of chicken, all farmers reared indigenous type (deshi). However, several breeds of duck namely, deshi, Khaki Campbell and Jinding were reared by farmers (Figure 2). Figure shows that $54 \%$ of the farmers reared only deshi ducks followed by rearing $13 \%$ Khaki Campbell and $6 \%$ Jinding. The proportion of farmers rearing deshi duck in this study was lower than that of Rahman (2009), who found $82.25 \%$ farmers reared deshi duck. Only three farmers reared pigeon and they did not identify their breed/variety.

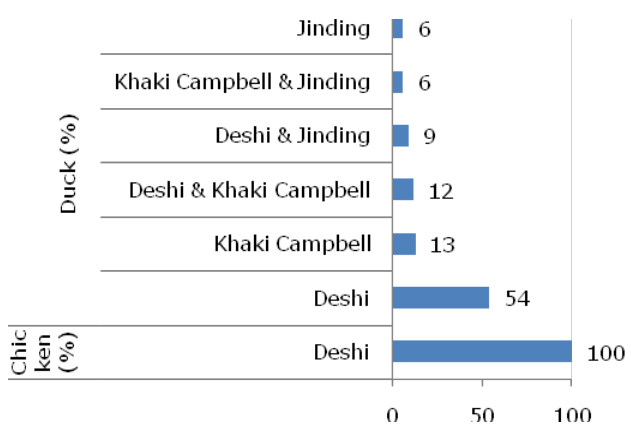

Figure 2. Different poultry breeds reared by farmers (\%)

\section{Population of poultry}

Poultry producers can be classified into three categories; namely low producer having less than 11 no's; medium producer having 12 to 22 no's and high producer having more than 22 no's of poultry. The number of chicken reared by each farmer ranged from 1 to 31 with an average of 10.4 (Table 1 ). The number of ducks ranged from 1 to 40 with an average of 9.95 (Table 1 ). There were only 3 farmers keept pigeons and their population per family ranged from 3 to 5 with an 


\section{Backyard poultry rearing}

average of 4 (Table 1 ). From the Table 1 , it can be seen that more than $50 \%$ farmers were low producers than medium and high producers.

Table 1: Categories of poultry producers

\begin{tabular}{lllll}
\hline Species & Category & $\begin{array}{l}\text { *Poultry } \\
\text { Farmer (\%) }\end{array}$ & $\begin{array}{l}\text { Average bird } \\
\text { /Farmer }\end{array}$ & SD \\
\hline \multirow{2}{*}{ Chicken } & Low (1-11) & $57.5(23)$ & & \\
& Medium (12-22) & $32.5(13)$ & 10.40 & 7.88 \\
& High (> 22) & $10.0(4)$ & & \\
\hline \multirow{3}{*}{ Duck } & Low (1-11) & $51.51(17)$ & & 9.02 \\
& Medium (12-22) & $30.30(10)$ & 9.95 & \\
\hline \multirow{3}{*}{ Pigeon } & High (>22) & $18.19(6)$ & & 0.81 \\
& Low (up to 11) & $100(3)$ & & \\
& Hedium (11-22) & 0 & 4.00 & \\
\hline
\end{tabular}

*Parenthesis indicates number of farmers; SD, standard deviation

\section{Poultry rearing system}

All farmers under the study area reared poultry in semi-scavenging system. The observation agrees with Jensen (1996) who reported that semiscavenging has recently been established in Bangladesh. More than 1 million semi-scavenging smallholder farms have been established and their number is growing at the rate of 1 lac annually.

Table 2. Housing patterns, bedding materials and cleanliness of poultry house

\begin{tabular}{lccc}
\hline Parameters & *Boyra (\%) & *Sutiakhali (\%) & Average (\%) \\
\hline \multicolumn{4}{l}{ Housing patterns of poultry } \\
Living house & $50(10)$ & $60(12)$ & 55.0 \\
House of tin and wood & $35(7)$ & $20(4)$ & 27.5 \\
House of tin and soil & $10(2)$ & $10(2)$ & 10.0 \\
Soil bamboo and wood & $5(1)$ & $10(2)$ & 7.5 \\
house & & & \\
\hline Bedding materials & & & \\
Ash & $60(12)$ & $75(15)$ & 67.5 \\
Sand & $25(5)$ & $15(3)$ & 20.0 \\
Paper and ash & $15(3)$ & $10(2)$ & 12.5 \\
\hline Cleaning of poultry house & & \\
Daily & $50(10)$ & $60(12)$ & 55.0 \\
Twice a week & $10(2)$ & $5(1)$ & 7.5 \\
Once a week & $30(6)$ & $25(5)$ & 27.5 \\
Once a fortnight & $10(2)$ & $10(2)$ & 10.0 \\
\hline
\end{tabular}

*Parenthesis indicate number of farmers

\section{Feeds and feeding of poultry}

Poultry farmer used a wide variety of supplementary feed for their poultry species. Study showed that about $62 \%$ of the farmers used boiled rice and rice polish other than using rice, rice polish, paddy, broken rice and wheat bran as feed ingredients for poultry in both villages (Figure 3 ).

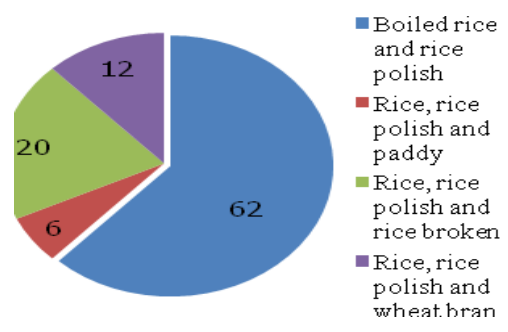

Figure 3. Ingredients used in poultry diet

\section{Housing of poultry}

Variation in housing pattern, bedding materials and frequency of cleaning of poultry house was observed. About 55\% farmers kept poultry in their living house while rest of farmers used wooden and tin shed house or soil and tin shed house or soil bamboo and wood shed house (Table 2). Halim (1988) observed in Naogaon district that 44,28 and $28 \%$ poultry were kept in bamboo cages, living house and earthen house, respectively. All farmers reported to use a common house for different types and age group of poultry. Predominating bedding materials were ash, sand and paper. It was observed that $67.5 \%$ farmers used ash then using sand or paper and ash together as a bedding material in their poultry house. It was also reported that over fifty percent farmers clean their poultry house daily (Table 2 ).

The farmers did not follow any specific composition while mixing ingredients. About $65 \%$ farmers provided feed to their poultry twice in a day during morning and evening (Figure 4).

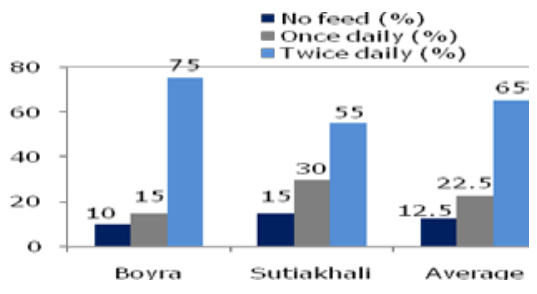

Figure 4. Frequency of feeding poultry 
The amount of feed supplied to chicken ranged from 35 to $60 \mathrm{~g} / \mathrm{d}$ and duck ranged from 90 to $125 \mathrm{~g} / \mathrm{d}$, with an average $48.5 \mathrm{~g} / \mathrm{d}$ and $108.12 \mathrm{~g} / \mathrm{d}$, respectively (Table 3 ). On the basis of feeds supplied to chicken and duck farmers were classified into 3 categories; namely low, medium and high. More than $40 \%$ and $60 \%$ farmers were supplied around 41 to $50 \mathrm{~g}$ feed per $d$ to their chicken and duck, respectively. The amount of supplemental feed/d of each chicken 48.50g, these findings is lower than that of Yeasmin et al. (2003). They investigated the feed intake $\mathrm{g} / \mathrm{d}$ of Rhode I sland Red, White Leghorn, Fayomi, Deshi normal and Deshi dwarf and reported the values 96.07, 92.71, 93.55, 75.10 and 57.81g, respectively. Present result also agrees with Rahman et al. (2009). They observed that 62 percent farmers gave supplemental feeding to their ducks amounting to $118 \mathrm{~g}$ per day to maximize egg production.

Table 3. Amount of feeds supplied to poultry daily

\begin{tabular}{llccc}
\hline \multirow{2}{*}{ Species } & \multicolumn{1}{c}{ Category } & $\begin{array}{c}\text { *Poultry Farmer } \\
\%\end{array}$ & Average & SD \\
\hline \multirow{3}{*}{ Chicken } & Low (up to 40g) & $22.5(9)$ & & \\
& Medium (41-50g) & $45(18)$ & 48.50 & 6.90 \\
& High (>50g) & $32.5(13)$ & & \\
\hline \multirow{2}{*}{ Duck } & Low (up to 95g) & $9.09(3)$ & & \\
& Medium (96-110g) & $66.67(22)$ & 108.12 & 8.06 \\
& High (>110g) & $24.24(8)$ & & \\
\hline
\end{tabular}

*Parenthesis indicate number of farmers; SD, standard deviation

\section{Use of feeder and waterer}

About $75 \%$ of farmers did not use feeder and $87.5 \%$ of farmers did not use waterer. In this rearing system, farmers were used mainly plastic or earth pot/ball for supplying feed and water of their poultry in both villages (Figure 5).

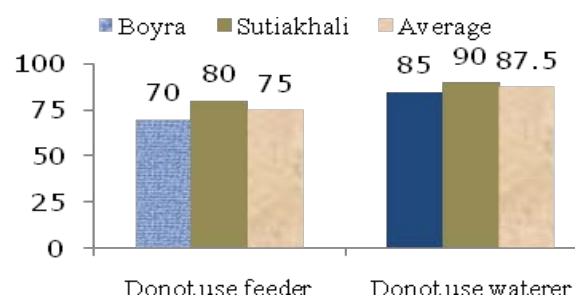

Figure 5. Use of feeder and waterer

\section{Productivity of poultry}

The study was captured age at sexual maturity, adult body weight, egg production, egg weight and hatchability of chicken and duck as productivity parameters that presented in Table 4 and 5 , respectively. Age at sexual maturity of chicken and duck varied from 180 to 220 days with an average of 189.25 and 194.77, respectively (Table 4 and 5). Among farmers, $37.5 \%$ obtained first egg of chicken at 180 days of age. About $42.42 \%$ of the farmers obtained first egg of duck at 190 days of age. This observation agrees with the previous report of Huque et al. (1992). He stated that the age of sexual maturity of deshi chicken varied between 190 to 200 days. This observation also agrees with I slam et al. (2003) and Sarker (2005). They reported the age of sexual maturity of deshi duck varied 180-210 days. Eswaran et al. (1984) observed age at first egg in 138 days for Khaki Campbell ducks vs. 158 days for deshi ducks. The observed result agrees with Huque et al. (1992). They stated that the weight of adult deshi chicken was 1.2 to $1.5 \mathrm{~kg}$. Present result also agrees with Islam et al. (2003) and Sarker (2005). They stated the weight of adult deshi duck was 1.5 to $1.8 \mathrm{~kg}$. This observation is also similar to that of Hamid et al. (1988). Egg production ranged from 35-52/chicken/year and 80-120/duck/year with an average of 42 and 102.87 eggs, respectively (Table 4 and 5). Among farmers, about 52.5\% obtained 40 eggs per chicken per year. However, egg production is higher for duck than that of chicken. About, $51.52 \%$ found $96-110$ eggs per duck per year. The observed result agrees with Bulbul (1983); Ahmed and Islam (1985). They reported that the egg production of adult deshi chicken was 35-40. The observation on egg production of duck was lower than that of Ukil (1992). He stated that deshi ducks laid 150-200 eggs per year under semi-scavenging system but the observation was higher than that of Islam et al. (2003) and Sarker (2005). They reported that the egg production of deshi duck 85$90 /$ duck/year. The weight of chicken and duck eggs ranged $35-44 \mathrm{~g}$ and $58-68 \mathrm{~g}$ with an average of $39.2 \mathrm{~g}$ and $62.5 \mathrm{~g}$, respectively (Table 4 and 5). The egg weight of chicken obtained coincides with that of Ahmed and Islam (1985) and Huque et al. 


\section{Backyard poultry rearing}

(1992). They reported the egg weight of deshi chicken was $35-39 \mathrm{~g}$. Present result of deshi duck coincides with that of Islam et al. (2003) and Sarker (2005). They reported the egg weight of deshi duck was $65 \mathrm{~g}$. The hatchability of chicken and duck egg ranged from 69 to $80 \%$ and 76 to $90 \%$ with an average of $75.97 \%$ and $83 \%$, respectively (Table 4 and 5). Approximately $50 \%$ of farmers got the hatchability more than $72 \%$ for chicken eggs (Table 4) and about $54.55 \%$ of farmers got the hatchability more than $84 \%$ for duck eggs (Table 5). Present result of chicken egg hatchability was lower than that of Azharul et al. (2005) and Khatun et al. (2005). Azharul et al. (2005) investigated that hatchability of broody hens under Bangladesh condition was $86.6 \%$. Khatun et al. (2005) showed that the hatchability on fertile eggs ranged from 78.33 to $90.79 \%$ in different genotypes of native chicken. On the other hand, hatchability of duck egg was higher than that of Rahman (2009) and Hamid et al. (1988). Rahman (2009) found $79 \%$ hatchability of duck egg and Hamid et al. (1988) reported the hatchability of deshi ducks as $66 \%$.

Table 4. Productivity of chicken

\begin{tabular}{lllll}
\hline Parameters & Category & *Farmer (\%) & Average & SD \\
\hline \multirow{2}{*}{$\begin{array}{l}\text { Sexual } \\
\text { maturity }\end{array}$} & Early (<180 d) & $37.5(15)$ & & \\
& Moderate (181-190 d) & $37.5(15)$ & 189.25 & 10.22 \\
& Late (>190 d) & $25(10)$ & & \\
\hline \multirow{2}{*}{ Adult } & Low (up to 1100g) & $32.5(13)$ & & \\
weight & Medium (1101-1250g) & $40(16)$ & 1192.5 & 122.23 \\
& High (>1250g) & $27.5(11)$ & & \\
\hline \multirow{2}{*}{ Egg } & Low (up to 40) & $52.5(21)$ & & \\
production & Medium (41-45) & $30(12)$ & 42 & 4.54 \\
& High (>45) & $17.5(7)$ & & \\
\hline \multirow{2}{*}{ Egg } & Low (up to 38g) & $40(16)$ & & \\
weight & Medium (39-41g) & $45(18)$ & 39.02 & 2.3 \\
& High (>41g) & $15(6)$ & & \\
\hline \multirow{2}{*}{ Hatchability } & Low (up to 71) & $10(4)$ & & \\
(\%) & Medium (72-76) & $50(20)$ & 75.97 & 2.87 \\
& High (>76) & $40(16)$ & & \\
\hline
\end{tabular}

"Parenthesis indicate number of farmers; SD, standard deviation

\section{Disease of poultry}

Diseases that outbreak frequently in the study area are presented in Table 6 . From Table 6 , it was observed that $51 \%$ and $49 \%$ farmers stated that their chickens and ducks were affected with New castle and duck cholera, respectively in both villages which was mostly prevalent disease. This finding coincides with that of Mohanty (1987) and Saha (2003). They reported that the most prevalent disease of deshi chicken was New castle, followed by Fowl pox, Coccidiosis, respiratory problems and other miscellaneous diseases.

Table 5. Productivity of duck

\begin{tabular}{|c|c|c|c|c|}
\hline Parameters & Category & ${ }^{\star}$ Farmer (\%) & Average & SD \\
\hline \multirow{3}{*}{$\begin{array}{l}\text { Sexual } \\
\text { maturity }\end{array}$} & Early (<190 d) & $42.42(14)$ & \multirow{3}{*}{194.77} & \multirow{3}{*}{10.37} \\
\hline & Moderate $(191-205 d)$ & $45.46(15)$ & & \\
\hline & Late $(>205 d)$ & $12.12(4)$ & & \\
\hline \multirow{3}{*}{$\begin{array}{l}\text { Adult } \\
\text { weight }\end{array}$} & Low (up to $1500 \mathrm{~g}$ ) & $15.15(5)$ & \multirow{3}{*}{1690.00} & \multirow{3}{*}{137.84} \\
\hline & Medium (1501-1750g) & $51.52(17)$ & & \\
\hline & High $(>1750 \mathrm{~g})$ & $33.33(11)$ & & \\
\hline \multirow{3}{*}{$\begin{array}{l}\text { Egg } \\
\text { production }\end{array}$} & Low (up to 95) & $33.33(11)$ & \multirow{3}{*}{102.87} & \multirow{3}{*}{9.86} \\
\hline & Medium (96-110) & $51.52(17)$ & & \\
\hline & High $(>110)$ & $15.15(5)$ & & \\
\hline \multirow{3}{*}{ Egg weight } & Low (up to 61g) & $36.36(12)$ & \multirow{3}{*}{62.50} & \multirow{3}{*}{2.56} \\
\hline & Medium (62-65g) & $57.58(19)$ & & \\
\hline & High $(>65 g)$ & $6.06(2)$ & & \\
\hline \multirow{3}{*}{$\begin{array}{l}\text { Hatchability } \\
(\%)\end{array}$} & Low $(<84 \%)$ & $33.33(11)$ & \multirow{3}{*}{83.00} & \multirow{3}{*}{2.70} \\
\hline & Medium (84-88\%) & $54.55(18)$ & & \\
\hline & High (>88\%) & $12.12(4)$ & & \\
\hline \multicolumn{5}{|c|}{$\begin{array}{l}\text { *Parenthesis indicate number of farmers; } \\
\text { standard deviation }\end{array}$} \\
\hline \multicolumn{5}{|c|}{$\begin{array}{l}\text { The results agree with more or less similar to that } \\
\text { of Rahman (2009) and Baki et al. (1986). } \\
\text { Rahman (2009) found, } 100 \% \text { of the duck owners } \\
\text { in Noakhali Sadar and Ramgati reported that the } \\
\text { most prevalent diseases of ducks were Plague and } \\
\text { Cholera. Baki et al. (1986) mentioned that Duck } \\
\text { Plague and Duck Cholera are the common } \\
\text { diseases of epidemic nature in Bangladesh. }\end{array}$} \\
\hline \multicolumn{5}{|c|}{ Table 6: I mportant diseases of poultry } \\
\hline Species & Diseases & & Farmers ( & \\
\hline \multirow{4}{*}{ Chicken } & New castle & & \multicolumn{2}{|l|}{51} \\
\hline & Fowl pox & & \multicolumn{2}{|l|}{27} \\
\hline & Fowl cholera & & \multicolumn{2}{|l|}{13} \\
\hline & No disease & & \multicolumn{2}{|l|}{$y$} \\
\hline \multirow{4}{*}{ Duck } & Duck cholera & & \multicolumn{2}{|l|}{49} \\
\hline & Duck plague & & \multicolumn{2}{|l|}{22} \\
\hline & Limber neck poisor & & \multicolumn{2}{|l|}{11} \\
\hline & No disease & & \multicolumn{2}{|l|}{18} \\
\hline
\end{tabular}


Among the farmers in both villages about $86 \%$ did not vaccinate their poultry because of lack of facilities and knowledge of vaccination (Figure 6).

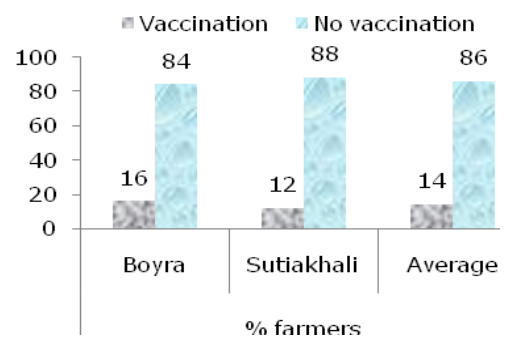

Figure 6: Use of vaccine in poultry

\section{Mortality of poultry}

Mortality of chicken and duck ranged from 10 to $37 \%$ with an average of 27.82 and $20.4 \%$, respectively (Table 7 ). The mortality in this observation is higher than that of Ershad (2005). He mentioned that the mortality of deshi chicken was $14.5 \%$. The mortality in this observation is lower than that of Huque and Husain (1994) and Khanum et al. (2005). Huque and Husain (1994) reported that the mortality of Khaki Campbell and Deshi duck were $58 \%$ and $72 \%$, respectively. Khanum et al. (2005) reported that the mortality of duck in Netrokona was $27.1 \%$.

Table 7: Mortality (\%) of chicken and duck

\begin{tabular}{cllll}
\hline Species & Categories & $\begin{array}{l}{ }^{*} \text { Poultry } \\
\text { Farmer (\%) }\end{array}$ & Average & SD \\
& & & \\
\hline \multirow{3}{*}{ Chicken } & Low (up to 20) & $12.5(5)$ & & \\
& Medium (21-30) & $52.5(21)$ & 27.82 & 5.94 \\
& High (>30) & $35(14)$ & & \\
& Low (up to 15) & $18.18(6)$ & & \\
Duck & Medium (16-25) & $66.67(22)$ & 20.4 & 6.02 \\
& High (>25) & $15.15(5)$ & & \\
\hline
\end{tabular}

*Parenthesis indicate number of farmers; SD, standard deviation

\section{Source of poultry}

There are some ways of getting poultry by farmers. A large number of farmers did not purchase bird or borrow from anywhere. They incubate chicken and duck egg under broody hen to get baby chicks and duckling. The farmers incubating eggs of chicken and duck for baby chicks and ducklings were 50\% and 43\%, respectively (Figure 7 ). Moreover, they go to market and neighbors (18\% and $32 \% ; 21 \%$ and
$36 \%$, for chicken and ducks, respectively) for getting poultry (Figure 7).

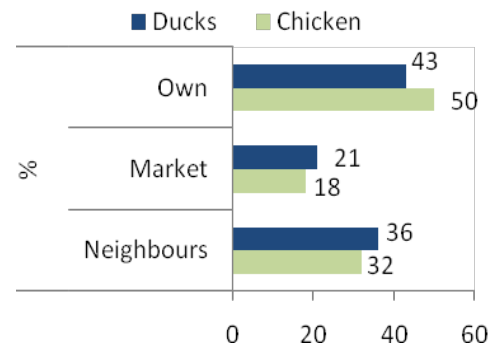

Figure 7: Sources of chicken and ducks

\section{Constraints of backyard poultry}

Traditional methods, scarcity of feed, lack of appropriate housing facilities, disease prevalence, inadequate supply of vaccine and medicine, attack of predators were identified as the major problems for backyard poultry rearing.

\section{Recommendation to improve backyard poultry}

> For increasing the productivity of backyard poultry, provision of high yielding varieties of deshi birds will be introduced.

$>$ A systemic training program needs to be organized for the village women on rearing management of poultry.

$>$ Availability of feed, medication and vaccination to farmers at reasonable price will have to increase the productivity of backyard poultry

$>$ A large number of farmers did not use vaccine to prevent diseases. So it's needed to be strengthened to educate the farmers on taking prevention and curative measures against diseases. Support from the Government to develop backyard poultry into a viable venture is required.

- Extension and motivational works should be carried out in the villages to encourage the farmers to increase the level of poultry operation pattern.

\section{Conclusion}

The study concluded that backyard poultry farmers were low producers and chicken and duck were found to be the most common poultry species reared by the farmers. Poultry rearing knowledge such as breeding, feeding, housing, 


\section{Backyard poultry rearing}

prevention and control of diseases are not satisfactory of the farmers. Therefore, a needbased extension program should be introduced among the farmers giving more focus on building awareness and ability about poultry production.

\section{References}

Ahmed S, Islam N (1985). Backyard Poultry Development Project in 100 Villages. Proceedings of the $1^{\text {st }}$ Conference of Bangladesh Animal Husbandry Association. Bangladesh Agricultural Research Council, Dhaka.

Azharul IM, Ranvig H, Howlider MAR (2005). Incubation capacity of broody hen and chicken performance in Bangladesh. Livestock Research for Rural Development, 17: 1-10.

Baki MA, Sarker AJ, Mondal MMH (1986). Pathological investigation on the mortality of ducks in Bangladesh. Proceedings of workshop, Bangladesh Agricultural University, Research Progress, held at Bangladesh Agricultural University on 4-5 October.

Besbes B (2009). Genotype evaluation and breeding of poultry for performance under suboptimal village conditions, World's Poultry Science J ournal, 65: 260-271.

Bulbul SM (1983). More protein for the undernourished through a village poultry project. Maximum livestock production from minimum land. Proceedings of the $4^{\text {th }}$ seminar held in Bangladesh Agricultural University, Mymensingh, Bangladesh.

Das SR (1995). A study on production and marketing of poultry products in Sylhet Sadar Thana. MS Thesis, Department of cooperation and marketing, Bangladesh Agricultural University.

Ershad SME (2005). Performance of hybrid layers and native hens under farms management in selected area of Bangladesh. International Journal of Poultry Science, 4: 228-232.

Eswaran KR, Ramakrishnan A, Venugopalan CK, Nair GR (1984). Comparative perfor-mance of Khaki Campbell and Deshi ducks. 2. Egg production, feed efficiency and egg quality. Indian Journal of Poultry Science, 20: 4245.
FAO/APHCA (2008). Asian milk for health and wealth.

Halim A (1988). Institutional reports on farming system research with particular reference to activities on livestock and poultry, Livestock Component of Farming System Research in Bangladesh. 21 $1^{\text {st }}$ Dec., 1988. Bangladesh Agricultural Research Council, Dhaka, Bangladesh.

Hamid MA, Chowdhury SMRK, Chowdhury SD (1988). A comparative study of the performance of growing ducklings of Khaki Campbell, Indian Runner and Indigenous ducks under farm conditions. Indian Journal of Poultry Science, 23: 118-121.

Huque QME, Hossain MJ (1994). Comparative performance of three genotypes of ducks under rural conditions. Bangladesh J ournal of Scientific Research, 12: 157-160.

Huque QME, Ukil MA, Haque ME, Hossain MJ (1992). Nutritional status of scavenging hen in Bangladesh. Bangladesh Journal of Scientific and Industrial Research, 10: 217222.

Islam MA, Nishibori M (2009). Indigenous naked neck chicken: a valuable genetic resource for Bangladesh. World's Poultry Science Journal, 65: 125-138.

Islam MN, Huque QME, Uddin MS, Sarker MSK (2003). Potentiality of native genotypes of Ducks. Proceedings of Third International Poultry Show and Seminar, World's Poultry Science Association, Bangladesh Branch, Dhaka, 259-270.

Jabbar MA, Geen DAG (1983). The Status and Potential of Livestock with in the Context of Agricultural Development Policy in Bangladesh. Aberystyth, the University College, Wales, UK.

Jensen HA (1996). "Semi-scavenging poultry flock", in Frands Dolberg and Poul Henning Petersen (eds.), Integrated Farming in Human Development, Proceeding of the Workshop March 25-29, Tune Landboskole, Denmark, 56-63.

Khanum J, Chwalibog A, Huque KS (2005). Study on rural duck production systems in selected areas of Bangladesh. Livestock Research for Rural Development, 17: 113.

Khatun R, I slam MS, Faruque S, Azmal SA, Uddin MS (2005). Study on the productive and 
Alam et al. (2014) Bang. J. Anim. Sci. 43 (1): 30- 37

reproductive performance of 3 native genotypes of chicken under intensive management. Journal of Bangladesh Agricultural University 3: 99-104.

Mohanty G (1987). Poultry health programme for rural poultry development. Paper presented at the FAO expert consultation on rural poultry development in Asia, Dhaka.

Muchadeyi FC, Wollny CBA, Eding $\mathrm{H}$, Weigend S, Makuza M, Simianer H (2007). Variation in village chicken production systems among agro-ecological zones of Zimbabwe. Tropical Animal Health and Production, 39: 453-461.

Rahman MM (2009). Development of feeding strategy for ducks raised by small farmers in coastal areas of Bangladesh. M.S. Thesis, Department of Poultry Science, Bangladesh Agricultural University, Mymensingh.

Rahman MM, Khan MJ, Chowdhury SD, Akbar MA (2009). Duck rearing system in southern coastal districts of Bangladesh. Bangladesh J ournal of Animal Science, 38: 132-141.

SAEDF (2008). South Asia Enterprise Development Facility, a multi-donor facility managed by the International Finance Corporation of the World Bank Group, Dhaka, Bangladesh.

Saha D (2003). Status of rural poultry production in North 24 Parganas district of West Bengal. MVSc Thesis, Division of Extension Education, IVRI, Izatnagar.

Sarkar K (2005). Duck farming for resource-poor farmers in Bangladesh. In: Proceedings of the $4^{\text {th }}$ International Poultry Show and Seminar, Dhaka, Bangladesh. World's Poultry Science Association, Bangladesh Branch, Dhaka, 130-141.

Ukil MA (1992). Availability of nutrients to scavenging chickens and ducks in Bangladesh. M. Sc. Thesis, Department of Poultry Science, Bangladesh Agricultural University, Mymensingh.

Yeasmin T, Howlider MAR, Ahammad MU (2003). Effect of introgressing dwarf gene from Bangladesh indigenous to exotic breeds on egg production. International Journal of Poultry Science, 2: 264-266. 